\title{
Digitalizácia (nielen) správy daní v Českej republike
}

\section{Digitalization of (not only) Tax Administration in Czech Republic}

\author{
Mgr. Bc. Katarína Kolbenhayerová - Mgr. Ing. Tereza Homa
}

DOI https://doi.org/10.33542/SCD21-0043-1-15

\begin{abstract}
Abstrakt
Téma digitalizácie je $\mathrm{v}$ dnešnej dobe skloňovaná stále viac a viac, a to nie len politickými predstavitel'mi, ale aj médiami. V dnešnej dobe je kladený takisto vel'ký doraz na zapracovanie digitalizácie i do právnych aktov štátov. V dnešnej globalizovanej spoločnosti je nutné, aby procesy prebiehajúce $v$ štátnej správe boli čo najefektívnejšie a najflexibilnejšie. V daňovej oblasti tomu určite napomáha portál MOJE DANE, ktorému sa v tomto príspevku budú autorky venovat'. Ďalším zaujímavým projektom, ktorý autorky v rámci tohto článku predstavia je projekt SONIA alebo banková identita. V tomto príspevku autorky predstavia kroky $\mathrm{k}$ digitalizácii štátnej správy a zamerajú sa predovšetkým na tie, ktoré priniesla novela daňového rádu a zákona o bankách.
\end{abstract}

\section{Kl’účové slová:}

digitalizácia, MOJE DANE, Bank ID, správa daní, štátna správa, projekt SONIA

\begin{abstract}
Today, the topic of digitization is becoming more and more discussed, not only by political leaders, but also by the media. There is a focus on incorporation of digitization into the legal acts of states. In today's globalized society, it is essential that the processes taking place in the state administration must be as efficient and flexible as possible. In the field of taxation, the MY TAXES portal, which the authors will focus on in this article, certainly helps. Another interesting project that the authors will present in this article is - the SONIA project or bank identity. In this article, the authors present the steps to digitize the state administration and focus primarily on those brought by the amendment to the Tax Code and the Banking Act.
\end{abstract}

Key words:

digitalization, MOJE DANE, Bank ID, tax administration, state administration, project SONIA JEL kód: K34 


\section{ÚVOD}

Rýchlost' rozvoja moderných technológii nabrala v druhej dekáde 21. storočiach na obrátkach. ${ }^{1}$ Vo vyspelých krajinách postupujú moderné technológie a hlavne ich digitálna podoba všetkými sférami každodenného l'udského života. Je zrejmé, že v poslednej dobe vidíme i rapídny vývoj v oblasti digitalizácie štátnej správy. Vzostup digitalizácie je možné ilustrovat' na príklade elektronických podaní. ${ }^{2}$ Ich zavedenie do portálu Finančnej správy českej republiky bolo v prvej dekáde 21. storočia očakávané, ale chvíl'u trvalo, kým si užívatelia na túto možnost' zvykli a začali túto možnost' aktívne využívat'. V nasledujúcich rokoch došlo k rapídnemu uprednostňovaniu elektronických podaní cez portál a mnoho l'udí dodnes uprednostňuje podania cez dátovú schránku.

Je otázkou, či obdobnú popularitu dosiahnu i novšie inštrumenty. Autorky tohto príspevku sa preto rozhodli zmapovat' posledné míl'niky digitalizácie správy daní a obecne finančnej správy za posledné obdobie. Autorky sa sústredia hlavne na rok 2020 a 2021, ked’že vtedy sa v Českej republike realizovali hned' dva významné projekty v oblasti digitalizácie. I ked' je momentálne možné vidiet' nielen ich pozitíva ale i negatívna, pozitíva aktuálne prevládajú. Od budúcna bude samozrejme vel'mi dôležité sledovat' ich vývoj kritickým okom.

\section{DIGITALIZÁCIA ŠTÁTNEJ SPRÁVY}

To, že je digitalizácia téma dnešnej doby nie je nutné d’alej predstavovat'. Ked’že je táto téma pomerne abstraktná, konkrétne fakty vyplývajú zo súhrnnej správy o digitalizácii verejnej správy v Českej republike vydanej Najvyšším kontrolným úradom („súhrnná správa“). $\mathrm{V}$ uplynulých siedmych rokoch putovali masívne investície do informačnej infraštruktúry štátu, ktorá si z hl'adiska technickej vyspelosti vedie vel’mi dobre. Výdaje organizačných zložiek štátu a štátnych fondov na informačné a komunikačné technológie (,ICT“) činili od roku 2012 do roku $201875 \mathrm{mld}$. Kč ${ }^{3}$, približne dve desiatky miliárd potom činili výdaje preplácané z EÚ fondov na rozvoj digitalizácie verejnej správy. I cez pomerne vel'ké množstvo investícii však občania nemohli zatial' riešit' vel'ké množstvo záležitostí z domu, prípadne z mobilného telefónu. To bolo vel'mi očividné v období lock-downu zapríčineným pandémiou COVID-19. V tom čase štátna správa obmedzila svoju činnost' na minimum.

Je tu však i iná možnost', a síce, že o digitalizáciu nie je zo strany občanov taký záujem. Podla súhrnnej správy v roku 2018 využilo 26 \% fyzických osob pre komunikáciu s úradmi online služby. Štatistiky týkajúce sa dátových schránok ukazujú, že dobrovol’ne si dátovú schránku zriadilo len 2 \% fyzických osôb nepodnikatel’ov. Doplňujeme, že v roku 2018 sa

\footnotetext{
${ }^{1}$ Informace o činnosti daňové správy České republiky za rok 2002. [online]. Finanční správa [cit. 2021-08-13]. https://www.financnisprava.cz/assets/cs/prilohy/fs-vysledky-cinnosti/CinnostDS2002.pdf

2 Počty podání EPO 2003 - 2013. [online]. Finanční správa [cit. 2021-08-13]. https://www.financnisprava.cz/cs/dane-elektronicky/danovy-portal/pocty-podani-epo/pocty-podani-epo-20032008?fbclid=IwAR2mPtXx9KLuGsW4W9Qouk9rIpwXG91 KSAQFVs5QyEiOzMJ84uSkMdUPunk

${ }^{3}$ Digital Economy and Society Index (DESI) 2018 Country Report Czech Republic. [online].ec.europa.eu[cit. 2021-08-13]. http://ec.europa.eu/information_society/newsroom/image/document/2018-20/cz-desi_2018country-profile_eng_B43F6E27-BF54-1844-69A6178486494991_52216.pdf.
} 
uskutočnilo 97 miliónov transakcii prostredníctvom dátových schránok, ale len 0,65 \% z nich uskutočnili nepodnikajúce fyzické osoby. ${ }^{4}$

Dôvodom pre neefektívne alebo nedostatočné nastavenie, ale taktiež využívanie digitálnych služieb verejnej správy je hned' niekol'ko. Jedná sa o nedostatočnú legislatívnu pripravenost' na d’alšiu digitalizáciu, zastaranost' ICT systémov jednotlivých zložiek verejnej správnym zle nastavené podmienky spolupráce s externými dodávatel'mi systém výkonu finančnej správy nie je centralizovaný a v neposlednej rade nie je dostatok personálnych kapacít, ktoré by ICT systémy udržovali vo funkčnosti a starali sa o ich modernizáciu.

Z mnohých vyššie uvedených problematických bodov je v procese riešenia. Napríklad za hlavný orgán koordinujúci informačné a komunikačné technológie je možné považovat' Ministerstvo vnútra. Problematická oblast' nedostatku pracovníkov ICT služieb vo verejnej správe korešponduje obecne s vel'mi nízkou mierou nezamestnanosti, ktorá sa v Českej republike pohybuje okolo $2 \%$. Na jednu stranu zamestnancov v IT službách pomerne pribúdajú, avšak tí putujú primárne do súkromnej sféry.

Čo sa týka legislatívneho základu pre možný rozvoj digitalizácie verejnej správy v Českej republike, tak pomernou novinkou, a pritom hlavným zákonom je tzv. digitálna ústava. Tá upravuje právo fyzických a právnických osôb na poskytnutie digitálnych služieb orgánmi verejnej moci pri výkone ich pôsobnosti, právo fyzických osôb a právnických osôb činit' digitálne úkony, povinnost' orgánov verejnej moci poskytovat' digitálne služby a prijímat' digitálne úkony a niektoré d’alšie práva a povinnosti súvisiace s poskytovaním digitálnych služieb.

V tomto príspevku sa autorky zameriavajú predovšetkým na digitalizáciu daňovej a finančnej správy. Ďalej predstavia koncept MOJE DANE a bankovej identity alebo Bank ID.

\section{SÚČASNÉ RIEŠENIE DAŇOVEJ INFORMAČNE SCHRÁNKY A MOJE DANE}

V súčasnej dobe ponúka daňová správa len pár možností pre občanov ako komunikovat' a činit' úkony prostredníctvom vzdialených prístupov. Jedným z nich je daňová informačná schránka (,DIS“). V DIS sú dostupné informácie o stave osobného daňového účtu v členení podla jednotlivých druhov daní, prehl'ad písomností medzi daňovým subjektov a správcom dane a daňový kalendár s prehl'adom daňových povinností. Prístup do DIS je možný v prípade, že má daňový subjekt sprístupnenú Dátovú schránku alebo vlastný Kvalifikovaný certifikát. Pokial' má osoba toto k dispozícii, musí následne formálne zažiadat' skrz elektronickú žiadost' o zriadenie Daňovej informačnej schránky.

\footnotetext{
${ }^{4}$ Digital Economy and Society Index (DESI) 2018 Country Report Czech Republic. [online].ec.europa.eu[cit. 2021-08-13]. http://ec.europa.eu/information_society/newsroom/image/document/2018-20/cz-desi_2018country-profile_eng_B43F6E27-BF54-1844-69A6178486494991_52216.pdf.
} 
DIS je vhodným nástrojom pre všetkých, ktorí chcú mat' svoje daňové záležitosti pod kontrolou. DIS je zatial' samozrejme nedokonalý, vykazuje niekol'ko nedostatkov a má len obmedzené funkcie prostredníctvom ktorých je možné sledovat' len možné nedoplatky na jednotlivých daniach a z nich plynúce sankcie. ${ }^{5}$

Cestou k modernizácii a digitalizácii daňovej správy v Českej republike je novela daňového rádu, ktorej konečné znenie podpísal prezident republiky. Elektronizácia finančnej správy je významným krokom k modernizácii celého systému využívaného daňovými subjektmi. Vízia jednotlivých zmien bola jasná - tj. ul'ahčit' občanom komunikáciu so správcom dane a znížit' administratívnu náročnost' tejto komunikácie. V praxi to znamená zavedenie portálu zvaného MOJE DANE, ktorý má byt' rozšírením už dostupnej služby DIS. Aktuálny systém umožňuje daňovému subjektu získavat' informácie zhromaždené v spise a na osobnom daňovom účte poplatníka prostredníctvom internetu

Nový portál MOJE DANE ponúka okrem informácii aj možnost' aktívne a pasívne komunikovat' so správcom dane, napríklad umožňuje podávat' daňové priznania prostredníctvom online formulárov, ktoré umožňujú určitú mieru pred vyplnenia údajov daňových subjektov. Komunikácia by však mala fungovat' i v opačnom smere, teda od správcu dane $\mathrm{k}$ daňovému subjektu, $\mathrm{v}$ zmysle doručovania písomností. Ministerstvo financií spustilo portál 28. februára 2021 a od tej doby ho mohlo otestovat' pomerne vel'ké množstvo daňových subjektov. Nie všetci sú však z portálu nadšení. Niektoré recenzie portálu poukazujú na to, že určité stránky portálu nie sú dostatočne užívatel'sky jednoduché. ${ }^{6}$ Autorky príspevku však veria, že spätná väzba je v tomto prípade vel'mi potrebná a nové verzie portálu tieto nedostatky určite napravia.

Je možné očakávat', že do budúcna budeme teda s daňovou správou komunikovat' zväčša na báze „elektronického bankovníctva“, prostredníctvom ktorého budeme môct' nielen hradit’ svoje daňové povinnosti, ale aj vybavovat' svoje písomnosti a komunikáciu so správcom dane. To znamená vel'ké zjednodušenie a krok k prehl'adnosti daňových procesov.

\section{BANKOVÁ IDENTITA - SONIA}

Ako už autorky príspevku poukazujú vyššie, Česká republika mala doteraz len obmedzené možnosti ako môžu občania komunikovat' so štátnymi orgánmi digitálne. Ku konci roku 2019 s účinnost'ou k 1. januáru 2021 bol poslaneckou snemovňou jednohlasne schválený projekt SONIA - súkromnoprávny bod pre identifikáciu a autentifikáciu.

Ciel'om projektu SONIA alebo bankovej identity je zjednodušit' formu a prístup ku službám českého e-governmentu i online službám v súkromnom ale i verejnom sektore. Projekt pomáha občanom, verejnej správe ale aj súkromným poskytovatel’om služieb. Banková identita je v súčasnosti už využívaným riešením v mnohých zahraničných štátoch. Najpokročilejšími

\footnotetext{
5 TULÁČEK, M. Elektronizace správy daní: právní aspekty. Praha: Leges, 2020.

${ }^{6}$ Vyzkoušeli jsme Moje daně od Schillerové. Ani moderní, ani jednoduché | Peníze.cz (penize.cz) [online].
} 
štátmi v používaní bankovej identity sú pobaltské a severské štáty, hlavne Nórsko, Dánsko alebo Švédsko.

Projekt SONIA nadväzuje na národný systém pre elektronickú identifikáciu, ktorú vybudoval štát a spustil v roku 2018. ${ }^{7}$ Občania sa môžu do e-governmentu prihlásit' prostredníctvom elektronického občianskeho preukazu alebo dátovej schránky. Toto riešenie sa však nedočkalo vel'kého úspechu a obsahovalo niekol'ko nedostatkov, na ktoré práve projekt SONIA reaguje. Jedným z nedostatkov predchádzajúceho riešenia bol jeho malý počet užívatel'ov. Len malé percento občanov využíva elektronický občiansky preukaz na svoju identifikáciu. Ďalším nedostatkom je fakt, že toto štátne riešenie nebolo dostupné pre komerčnú sféru poskytovatel’ov služieb. Podl'a $\S 2$ zákona o elektronickej identifikácii je možné elektronický preukaz použit' len vo vzt'ahu k službám verejnej moci a tých, ktorí overujú totožnost' na základe zákona. Projekt SONIA by nemal štátnemu riešeniu konkurovat' ale práve naopak. Ciel'om projektu je spojit' prostriedky k elektronickej identifikácii klientov bánk a vedl'a štátneho systému vybudovat' systém pre sprístupňovanie bankovej identity v súkromnom sektore.

Hlavná myšlienka bankovej identity je, aby občania Českej republiky mohli využívat' rovnaké bankové údaje, ktoré používajú pre vstup do svojho internetové bankovníctva ku všetkým službám. To má za ciel' ušetrit' čas aj peniaze nielen klientom, ale aj verejnej správe a súkromným podnikatel’om. V rámci Bank ID bude banka alebo pobočka zahraničnej banky oprávnená ponúkat', poskytovat' alebo sprostredkovávat' identifikačné služby. Banková identita slúži taktiež k podpisovaniu dokumentov a transakcii. Toto riešenie má zjednodušit' mimo iné i procesy, ktoré sú pre mnohé subjekty povinné skrz reguláciu legalizácie výnosov z trestnej činnosti a financovania terorizmu („AML“). Vd’aka tomuto riešeniu prišlo k digitalizácii procesov, ktoré sa viažu na identifikáciu klienta za jeho fyzickej prítomnosti. V praxi teda pre klientov zmizne povinnost' fyzickej návštevy banky alebo kontaktného miesta. ${ }^{8}$

Banková identita môže byt' v praxi využívaná mnohými spôsobmi, ktoré nie je aktuálne možné taxatívne vymedzit' a definovat'. Aktuálna verejná diskusia smeruje k hlavným spôsobom, ktoré sa autorky pokúsia d’alej definovat'. Asi hlavným využitím bankovej identity je tzv. „,univerzálny kl’uč“. Tento kl'úč by klientom sprístupňuje digitálne služby firiem i štátu. Pre prihlásenie k jednotlivým službám je používaný obdobný spôsob ako pri prihlasovaní sa do internetového bankovníctva. Klient si nemusí vytvárat' rôzne účty u rôznych spoločností, kde býva vel'mi problematická strata hesla či zneužitia jedného hesla, ktoré klient využíva u všetkých účtov rovnaké. Banková identita sa môže využívat' nielen k digitálnej identifikácii, ale aj k podpisovaniu dokumentov a transakcii. Bank ID splňuje oficiálne požiadavky na elektronický podpis. Klient môže tak dokument podpísat' pomocou bankovej identity. ${ }^{9}$

\footnotetext{
7 Projekt bankovní identita a jeho vývoj. [online]. Bankovní identita [cit. 2021-06-07]. https://bankovniidentita.cz/o-projektu/

${ }^{8}$ Důvodová zpráva k zákonu č. 49/2020 Sb., kterým se mění zákon č. 21/1992 Sb., o bankách, ve znění pozdějších předpisů, a zákon č. 2008 Sb., o některých opatřeních proti legalizaci výnosů z trestné činnosti a financování terorismu, ve znění pozdějších předpisů, a některé další zákony.

${ }^{9}$ Bankovní identita. Česká bankovní asociace [online].
} 
Ked’že banky robia vel'mi dôkladnú identifikáciu a kontrolu svojich klientov, majú o klientoch všetky potrebné údaje, ktoré vyžaduje AML zákon. Tieto údaje v rámci bankovej identity môžu širokej škály povinných osôb z AML zákona ul'ahčit' digitálne poskytovanie služieb klientom. V praxi to môže vyzerat' tak, že Bank ID sa využíva pri kúpi nehnutel'nosti alebo pri zjednávaní životného poistenia. ${ }^{10}$

Informácie, ktoré má banka v rámci Bank ID môžu byt' využívané d'alej pri overovaní veku. V prípade, že by klient vstupoval na webové stránky, ktoré majú obsah vhodné len pre osoby, ktoré dosiahli určitú vekovú hranicu, klient by bol overený skrz jeho Bank ID a nemusel by potvrdit' prehlásenie o dosiahnutí požadovaného veku. Na základe Bank ID môžu byt' klientom poskytované i d'alšie vel'mi personalizované služby.

Využívaním Bank ID je v praxi pre koncového užívatel'a banky a taktiež pre štát bezplatné. Za túto službu platia štandardne bankám ako poskytovatel’om elektronickej identifikácie platit' tretej strany, teda komerční poskytovatelia služieb. To, či bude banka tieto služby elektronickej identifikácie poskytovat', záleží len na jej vlastnom uvážení. Každá banka má pre toto rozhodnutie rovnaké zákonné podmienky.

Bank ID je pre oblast' digitalizácie pomerne vel'kým krokom. Na druhú stranu však so sebou nesie i možnosti právnych alebo faktických problémov. Ako jedna z hlavných oblastí, ktoré je potrebné v rámci bankovej identity sledovat', je ochrana osobných údajov. Banky aj tretie strany musia vynaložit' vel'ké finančné a technické úsilie na to, aby neprichádzalo k ret’azeniu bankových identít a tým neprišlo k zneužívaniu osobných klientov bánk. Údaje, ktoré má banka $\mathrm{k}$ dispozícii by mali byt' tretím stranám predávané len na základe súhlasu, ktorý klient banke udelí sám. Bez pokynu klienta tretej strane nemôže predat’ žiadne údaje. Použitie Bank ID je pre klient vždy dobrovol'né. Klient by mal vždy možnost' skontrolovat' údaje, ktoré banka tretím stranám poskytuje a musí mat' možnost' svoj súhlas odvolat'.

Predávaním Bank ID a d’alších údajov za účele ochrany osobných údajov by malo byt' založené v princípe minimalizácie. To znamená, že tretia strana, ktorá poskytuje napr. možnost' zakúpenia alkoholických údajov online, bude pre svoju činnost' potrebovat' len overenie veku, resp. naplnenie vekovej hranice. Banka by v tomto prípade určite nemala predávat' e-shopu iné informácie napr. konkrétny vek.

Ďalším problematickým bodom v rámci Bank ID sú vzt’ahy zodpovednosti. Právna úprava je doposial' pomerne nová a podl'a názorov autoriek príspevku nie je úplne jasné, kto a do akej miery bude zodpovedat' za škodu v prípade, že príde zneužitiu dát klienta z jeho bankovej identity. V tomto za najdôležitejšie považujú autorky zameranie sa na zmluvné vzt’ahy medzi bankami a tretími stranami.

\footnotetext{
${ }^{10}$ Bankovní identita. Česká bankovní asociace [online].
} 


\section{ZÁVER}

Budúcnost' určite spočíva vo využívaní technológii a je len otázka, ako sa mu rigidné procesy vo verejne správe prispôsobia. Digitálna ústavu je nutné vnímat' ako vel'ký krok vopred a prísl'ub do budúcna. Je zrejmé, že rastúca digitalizácia verejnej správy porastie a význam pojmov ako kybernetická bezpečnost' a ochrana osobných údajov budú stále významnejšie. Tieto i mnoho iných pojmov tak čakajú nové a nové výzvy.

Portál MOJE DANE predstavuje očakávaný krok dopredu, ktorý vláda Českej republiky avizovala už v roku 2016. Nie je preto prekvapivé, že tento krok bol naozaj potrebný, pretože transformácia od analógovej podoby daňových priznaní a nahliadania do spisovej v digitálnej podobe bola vel'mi pomalá. I ked' má portál MOJE DANE zatial' len základné funkcie chýbajú mu jazykové mutácie, jedná sa o vel'mi významný krok vpred. Už len to, že je možné sa na stav osobného daňového účtu možné pozriet' online a nie je nutné o nahliadnutie zažiadat' písomne, považujú autorky príspevku za vel'mi dôležité.

Banková identita je ešte stále aktuálnou témou. S určitost'ou môžeme povedat', že ovplyvnila a ešte ovplyvní fungovanie nielen digitálnych finančných služieb, ale i mnohé iné odvetvia. Namiesto toho, že len niekol'ko málo tisíc občanov Českej republiky komunikuje s úradmi prostredníctvom Portálu občana skrz dátové schránky alebo elektronické občianske preukazy, má milióny občanov prístup k e-governmentu skrz Bank ID. Autorky článku sú názoru, že v Českej republike ešte nebol iný projekt, ktorý by mal na využívanie digitálnych služieb vo verejnej sfére väčší dopad.

Pri implementácii bankovej identity a jej vplyve na d’alšie oblasti práve by sme však mali zostat' stále dostatočne kritickí a vnímat' riziká, ktoré so sebou digitalizácia samozrejme prináša. Banky a tretie strany by sa mali zamerat' na ochranu osobných údajov ich klientov, ktorá je v tomto ohl'ade kl’účová. Pri využívaní elektronickej identifikácie by mal byt' dodržovaný princíp minimalizácie poskytovaných údajov tak, aby nedochádzalo k využívaní osobných dát klientov nežiadúcim spôsobom.

Záverom príspevku by chceli autorky podotknút', že problematika digitalizácie a konkrétne bankovej identity a portálu MOJE DANE je pomerne nová. Odborná literatúra, ktorá by pokrývala túto problematiku na českom trhu nie je dostatočná a i práve z tohto dôvodu považujú autorky túto tému za vel'mi dôležitú. Autorky veria, že tejto problematike bude v rámci akademickej obce Českej ale i Slovenskej republiky venované viac priestoru.

\section{POUŽITÁ LITERATÚRA}

1. Daně online se blíží. [online]. E15.cz [cit. 2021-08-13]. Daně online - Jak podat daňové přiznání přes portál MOJE daně $\mid$ E15.cz 
2. Digital Economy and Society Index (DESI) 2018 Country Report Czech Republic. [online].ec.europa.eu[cit. 2021-08-13]. http://ec.europa.eu/information_society/newsroom/image/document/2018-20/czdesi_2018-country-profile_eng_B43F6E27-BF54-184469A6178486494991_52216.pdf.

3. Důvodová zpráva k zákonu č. 227/2000 Sb., o elektronickém podpisu

4. GREGUŠOVÁ, D., a HALÁSOVÁ, Z. Zákon o e-Governmente: komentár. Bratislava: Eurokodex, 2018

5. Informace o činnosti daňové správy České republiky za rok 2002. [online]. Finanční správa [cit. 2021-08-13]. https://www.financnisprava.cz/assets/cs/prilohy/fsvysledky-cinnosti/CinnostDS2002.pdf

6. Informace o činnosti daňové správy České republiky za rok 2003. [online]. Finanční správa [cit. 2021-08-13]. https://www.financnisprava.cz/assets/cs/prilohy/fsvysledky-cinnosti/CinnostDS2003.pdf

7. LAPÁČEK, J. Jak na datovou schránku a elektronickou komunikaci s úřady. Brno: Computer Press, 2012.

8. Počty podání EPO 2003 - 2013. [online]. Finanční správa [cit. 2021-08-13]. https://www.financnisprava.cz/cs/dane-elektronicky/danovy-portal/pocty-podaniepo/pocty-podani-epo-20032008?fbclid=IwAR2mPtXx9KLuGsW4W9Qouk9rIpwXG91KSAQFVs5QyEiOzM J84uSkMdUPunk

9. Portál MOJE daně. [online]. Moje daně [cit. 2021-08-13]. https://adisspr.mfcr.cz/pmd/home

10. Portál národního bodu pro identifikaci a autentizaci. SPRÁVA ZÁKLADNÍCH REGISTRŮ [online]. [cit. 2021-08-04]. Dostupné z: https://www.eidentita.cz/Home

11. Projekt bankovní identita a jeho vývoj. [online]. Bankovní identita [cit. 2021-04-05]. https://bankovni-identita.cz/o-projektu/

12. Radvan, M. Poznámka hostujícího editora k digitalizaci v právu. BRICS Law Journal. 2020; roč. 7, č. 2, s. 5-9. https://doi.org/10.21684/2412-2343-2020-7-2-5-9

13. TULÁČEK, M. Elektronizace správy daní: právní aspekty. Praha: Leges, 2020.

14. Vyzkoušeli jsme Moje daně od Schillerové. [online]. Peníze.cz [cit. 2021-08-13]. Vyzkoušeli jsme Moje daně od Schillerové. Ani moderní, ani jednoduché 1 Peníze.cz (penize.cz)

15. Zákon č. 253/2008, zákon o některých opatřeních proti legalizaci z trestné činnosti a financování terorismu, ve znění pozdějších předpisů In: Zákony pro lidi [online]. zakonyprolidi.cz [cit. 2021-08-13]. Dostupné z: https://www.zakonyprolidi.cz/cs/2008-253\#cast2

16. Zákon č. 49/2020 Sb., kterým se mění zákon č. 21/1992 Sb., o bankách, ve znění pozdějších předpisů, a zákon č. $2008 \mathrm{Sb}$., o některých opatřeních proti legalizaci výnosů z trestné činnosti a financování terorismu, ve znění pozdějších předpisů, a některé další zákony. In: Beck-online [online právní informační systém]. Nakladatelství C. H. Beck. [cit. 2021-08-13]. Dostupné z: https://www.beck- 
online.cz/bo/chapterview-

documentseam?documentId=onrf6mrqgiyf6nbzfuya \&groupIndex $=5 \&$ rowIndex $=0$

\section{KONTAKT NA AUTORA}

katarina.kolbenhayerova@gmail.com

Masarykova Univerzita, Právnická fakulta

Veveř́ 70

61180 Brno

Česká republika

terkakrizova@seznam.cz

Masarykova Univerzita, Právnická fakulta

Veveř́ 70

61180 Brno

Česká republika 